\title{
Research Note \\ Metacercariae of Centrocestus formosanus in goldfish (Carassius auratus L.) imported into Croatia
}

\author{
E. GJURČEVIĆ ${ }^{1}$, Z. PETRINEC ${ }^{1}$, Z. KOZARIĆ ${ }^{2}$, S. KUŽIR ${ }^{2}$, V. GJURČEVIĆ KANTURA ${ }^{2}$, M. VUČEMILO ${ }^{3}$, \\ P. DŽAJA ${ }^{4}$
}
${ }^{1}$ Department of Biology and Pathology of Fishes and Bees; ${ }^{2}$ Department of Anatomy, Histology and Embryology;
${ }^{3}$ Department of Animal Hygiene, Environment \& Ethology; ${ }^{4}$ Department of Forensic and Juridical Veterinary Medicine, Faculty of Veterinary Medicine, University of Zagreb, Heinzelova 55, Zagreb 10 000, Croatia, E-mail:egjurcevic@vef.hr

\begin{abstract}
Summary
The presence of metacercariae of Centrocestus formosanus was detected on the gills of goldfish (Carassius auratus L.) imported from Singapore and obtained from two pet shops. This is the first report of the parasite in Croatia. The histopathological changes observed lead to the conclusion that the infection could be one of the reasons for the death of goldfish.
\end{abstract}

Key words: Centrocestus formosanus; goldfish; histopathological changes

\section{Introduction}

Centrocestus formosanus (Nishigori, 1924) (Trematoda: Heterophyidae) has a complex life cycle, during which it uses a snail as the first intermediate host and several fish species as the second. The cycle is completed when a fish infected with metacercariae is eaten by a definitive host, piscivorous birds or fish-eating mammals, in whose digestive tract the adult trematode develops (Premvati \& Pande, 1974; Paperna, 1996; Scholz \& Salgado-Maldonado, 2000; Scholz et al., 2001; Hernández et al., 2003; Mitchell et al., 2005). The parasite has been found in the gills of many fish species from numerous Asian countries (Yanohara \& Kagei, 1983; Madhavi, 1986), United States (Mitchell et $a l ., 2000)$ and other parts of the world (Vélez-Hernández et al., 1998; Hernández et al., 2003; Salgado-Maldonado et al., 2005). In Turkey, Yildiz (2005) first recovered the metacercariae of $C$. formosanus from the gills of ornamental fish imported from Singapore.

\section{Material and Methods}

The study involved 50 goldfish imported from Singapore and obtained from two pet shops in Zagreb, Croatia. Wet mounts of gill tissue were observed under an optical microscope, Olympus BX41 at $40-1000 \mathrm{X}$. The gills of 10 infected goldfish were removed and placed in small Petri dishes. A $2.5 \%$ solution of Trypsin $(\mathrm{pH}=6,2)$ was added to the encysted metacercariae. Excysted metacercariae were identified as wet mounts under a microscope. Cysts and excysted metacercariae were measured with an Olympus DP 12 digital camera and Cell B software (Soft Imaging System). The mean values of all measurements are presented in $\mu \mathrm{m}$, and ranges are provided in parentheses. For histopathological examination, the gills of each fish were fixed in $10 \%$ buffered formalin and Bouin's solution. The fixed material was embedded in paraffin wax and serially sectioned. The $6 \mu \mathrm{m}$ thick sections were stained with hematoxylin and eosin (H\&E), Mallory's aniline blue and Azan (Sheehan \& Hrapchak, 1980).

\section{Results and Discussion}

Metacercariae of Centrocestus formosanus were found in $20(40 \%)$ of the 50 goldfish. Cysts, randomly distributed along the entire length of the gill filaments, were oval in shape, measuring 186 (165 - 205) x 138 (116 - 158). Excysted metacercariae were elongate and pyriform in shape, measuring $240(185$ - 323) x $114(94-130)$ and completely covered with tegumental spines. The oral sucker was located at the anterior end, $30(22-38)$ long, 41 (33 49 ) wide, with 32 circumoral spines in two rows around it. 
The pharynx was well developed, measuring $30(20-39) \mathrm{x}$ $21(16-28)$. The oesophagus was short, anterior to the ventral sucker, the intestine bifurcated into two caeca extending towards the posterior end to reach the anterior level of the excretory vesicle. The ventral sucker was oval, measuring $33(27-41) \times 40(32-45)$, and posterior to the middle of the body. The testes were oval, and symmetrical in the posterior third of the body. The left testis measured $27(23-34) \times 32(31-35)$, and the right testis $28(26-$ 34) $x 33(30-40)$. The ovary was oval, situated to the right of the median line, anterior to the excretory vesicle. The excretory vesicle was X-shaped, in the posterior third of the body, between the testes (Fig. 1).

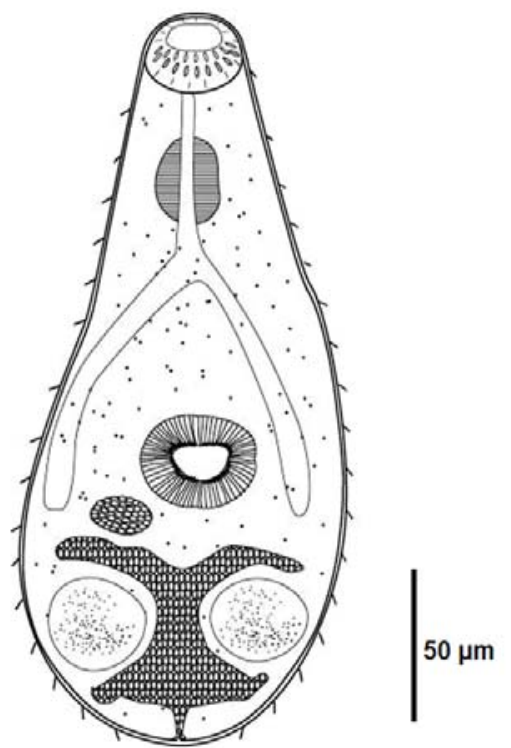

Fig. 1. Excysted metacercaria of Centrocestus formosanus, ventral view; free-hand drawing

Histopathologically, the changes were characterized by hyperplasia of the cartilage of the primary lamellae that envelops the metacercarial cysts. The metacercariae were surrounded by a $2-4 \mu \mathrm{m}$ thick refractile capsule. The host response included encapsulation around the cyst. The host cyst wall consisted of chondrocytes which were generally elongate adjacent to the parasites. On the periphery of the reaction, chondrocytes were rounded and hypertrophied. The majority of the cysts were encapsulated separately, and in only in a few cases did the capsule enclose more than one cyst. The infected part of the lamella very often caused fusion of two primary lamellae (Fig. 2). The majority of the histopathological changes were accompanied by the thickening and distorting of the primary lamellae. Hyperplasia of the epithelial cells resulted in partial and in some parts, total fusion of the secondary lamellae. Gill hyperaemia was also observed. There were sporadic hypertrophies of epithelial cells. Moderate mononuclear infiltration was present in the peripheral area of the lesion. Whilst researching the presence of parasites in goldfish kept in an aquarium, we found that $40 \%$ of the fish exa- mined were infected with $C$. formosanus. The finding of metacercariae of $C$. formosanus on the gills of goldfish is also the first report of this parasite in the Republic of Croatia. Arizmendi (1992) and Hernández et al. (2003) gave a detailed description of the morphological characteristics of the metacercariae. The morphometrical values found by these authors differ from each other. In this study, the morphometrical values do not agree with the findings of Arizmendi (1992) but they are in line with the findings of Hernández et al. (2003) with the exception of small differences in the size of the excysted metacercariae.

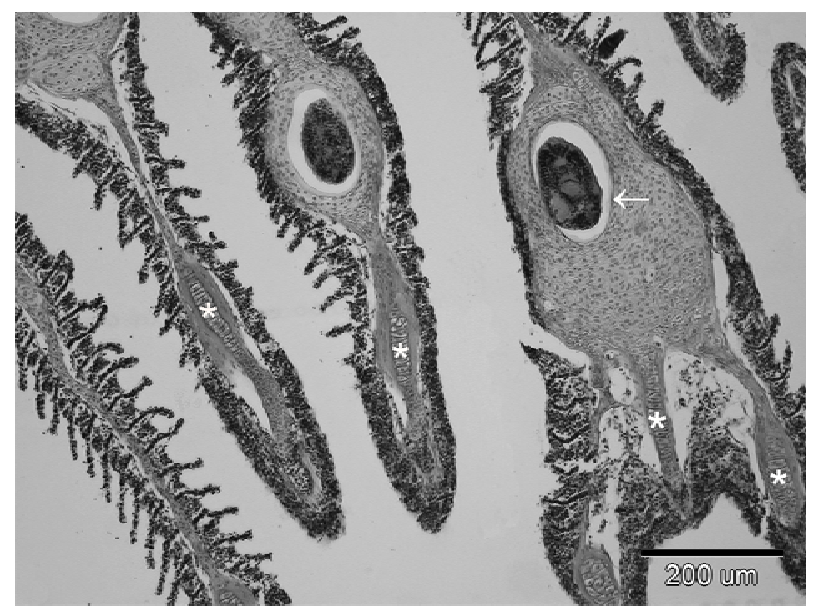

Fig. 2. Histological section of gills showing encysted metacercariae, fusion of gill filaments and hyperplasia of epithelial cells (HE) * Original filament cartilage; $\rightarrow$ Refractile capsule

According to Hernández et al. (2003), the metacercariae were $244-322 \mu \mathrm{m} \times 83-86 \mu \mathrm{m}$ and the oral sucker was $26-56 \mu \mathrm{m} \times 32-51 \mu \mathrm{m}$, whilst according to our research the metacercariae were $240(185$ - 323) $\mu \mathrm{m} \times 114(94-$ 130) $\mu \mathrm{m}$, and the oral sucker was $30(22-38) \mu \mathrm{m} \times 41(33$ - 49) $\mu \mathrm{m}$. Based on the number of circumoral spines and the characteristic shape of the excretory vesicle, we identified this parasite as Centrocestus formosanus (Nishigori, 1924).

The basic histopathological changes on the gills of the goldfish include hyperplasia of the cartilage of the primary lamellae that envelops the cysts, with the loss of respiratory surface. This histopathological finding is in line with the findings described by Blazer and Gratzek (1985), Vélez-Hernández et al. (1998), Mitchell et al. (2000) and Mitchell et al. (2002). We discovered hypertrophy of the epithelial cells of the secondary lamellae at the periphery of those changes, which had not been described by these authors. The hyperplasia of the gill cartilage discovered in our research was a defense reaction of the host tissue. Blazer and Gratzek (1985) made a similar observation. Our research, like that of Blazer and Gratzek (1985) and Mitchell et al. (2005), confirmed that histopathological changes cause reduction in the gill surface which leads to their decreased function. Since infection with $C$. formosanus metacercariae can cause fish death (Mitchell et al., 2000), quarantine and constant health monitoring are essential during goldfish importation. Further research is 
required to establish how great is the threat of introduction of these parasites into open waters in Croatia and of their further spread to indigenous fish species.

\section{Acknowledgements}

The authors would like to thank Tomáš Scholz, Institute of Parasitology, Academy of Sciences of the Czech Republic, Guillermo Salgado-Maldonado, Institute of Biology, National Autonomous University of Mexico, and Andrew J. Mitchell, Harry K. Dupree Stuttgart National Aquaculture Research Center, who enabled us to use their papers; Srđan Vučinić, Division of Molecular Medicine, Rudjer Boskovic Institute for help in data processing; Gordana Babac Pašagić and Nada Crnogaj, Department of Anatomy, Histology and Embryology, Faculty of Veterinary Medicine for technical assistance. We also appreciate the help of Ivanka Pašalić, GlaxoSmithKline Research Centre Zagreb Ltd.

\section{References}

ARIZMENDI, M. A. (1992): Descripción de algunas etapas larvarias y de la fase adulta de Centrocestus formosanus de Tezontepec de Aldama, Hidalgo. An. Inst. Biol. Univ. Nac. Auton. Mex. Ser. Zool., 63: 1-11

Blazer, V. S., GRATZEK, J. B. (1985): Cartilage proliferation in response to metacercarial infections of fish gills. J. Comp. Path., 95: 273-280

Hernández, L. E., Diaz, M. T., Bashirullah, A. K. (2003): Description of different developmental stages of Centrocestus formosanus (Nishigori, 1924) (Digenea: Heterophyidae). Rev. Cientif. FCV-LUZ, XIII(4): 285-292 MADHAVI, R. (1986): Distribution of metacercariae of Centrocestus formosanus (Nishigori, 1924) (Trematoda: Heterophyidae) on the gills of Aplocheilus panchax. J. Fish Biol., 29: 685-690

Mitchell, A. J., Salmon, M. J., Huffman, D. G., Goodwin, A. E., BrandT, T. M. (2000): Prevalence and pathogenicity of a heterophyid trematode infecting the gills of an endangered fish, the fountain darter, in two central Texas spring-fed rivers. J. Aquat. Anim. Health, 12: 283289

Mitchell, A. J., Goodwin, A. E., Salmon, M. J., BRANDT, T. M. (2002): Experimental infection of an exotic heterophyid trematode, Centrocestus formosanus, in four aquaculture fishes. N. Am. J. Aquacult., 64: 55-59

Mitchell, A. J., Overstreet, R. M., Goodwin, A. E., BRANDT, T. M. (2005): Spread of an exotic fish-gill trematode: A far-reaching and complex problem. Fisheries, 30: 11-16

PAPERNA, I. (1996): Parasites, infections and diseases of fishes in Africa. CIFA

Tech. Pap. FAO, Rome

Premvati, G., PAnde, V. (1974): On Centrocestus formosanus (Nishigori, 1924) Price, 1932 and its experimental infection in white leghorn chicks. Jap. J. Parasitol., 23: 79-84

SAlgado-Maldonado, G., Aguilar-Aguilar, R., Cabañas-Carranza, G., Soto-Galera E., MendozaPALMERo C. (2005): Helminth parasites in freshwater fish from the Papaloapan river basin, Mexico. Parasitol. Res., 96: 69-89

Scholz, T., SAlgado-MaldonAdo, G. (2000): The introduction and dispersal of Centrocestus formosanus (Nishigori, 1924) (Digenea: Heterophyidae) in Mexico: A Review. Am. Midl. Nat., 143: 185-200

Scholz, T., Aguirre-Macedo, M. L., SAlgadoMaldonAdO, G. (2001): Trematodes of the family Heterophyidae (Digenea) in Mexico: a review of species and new host and geographical records. J. Nat. Hist., 35: 1733-1772

Sheehan, D. C., HrapchaK, B. B. (1980): Theory and practice of Histotechnology. Battelle Press, ColumbusRichland

VÉlez-HernÁndeZ, E. M., CONSTANTINO-CASAS, F., GArcia-MÁrquez, L. J., OSORIO-SARABIA, D. (1998): Gill lesions in common carp, Cyprinus carpio L., in Mexico due to the metacercariae of Centrocestus formosanus. J. Fish Dis., 21: 229-232

YANOHARA, Y., KAGEI, N. (1983): Studies on the metacercariae of Centrocestus formosanus (Nishigori, 1924) - I. Parasitism by metacercariae on the gills of young cultured eels, and abnormal deaths of the hosts. Fish Pathol., 17: 237-241

YILDIZ, H. Y. (2005): Infection with metacercariae of Centrocestus formosanus (Trematoda: Heterophyidae) in ornamental fish imported into Turkey. Bull. Eur. Ass. Fish Pathol., 25: 244-246 